Relations industrielles

Industrial Relations

\title{
Cartels and Price Arbitration
}

\section{Maurice Lamontagne}

Volume 5, numéro 7, avril 1950

URI : https://id.erudit.org/iderudit/1023362ar

DOI : https://doi.org/10.7202/1023362ar

Aller au sommaire du numéro

Éditeur(s)

Département des relations industrielles de l'Université Laval

ISSN

0034-379X (imprimé)

1703-8138 (numérique)

Découvrir la revue

Citer cet article

Lamontagne, M. (1950). Cartels and Price Arbitration. Relations industrielles / Industrial Relations, 5(7), 63-66. https://doi.org/10.7202/1023362ar

Tous droits réservés @ C Département des relations industrielles de l’Université Laval, 1950
Ce document est protégé par la loi sur le droit d'auteur. L'utilisation des services d'Érudit (y compris la reproduction) est assujettie à sa politique d'utilisation que vous pouvez consulter en ligne.

https://apropos.erudit.org/fr/usagers/politique-dutilisation/ 
It is easy to establish the fact that the bishops of Quebec, after the Pope himself, are not the only ones to advocate these managerial reforms. The same can be said of many other passages in the letter on "the labour problem in the light of the social doctrine of the Church." Over and above the similarities between this document and those of the same type already issued in other countries, this episcopal document contains a goodly number of recommendations which apply especially to the province of Quebec. These two aspects of the joint letter bear witness at once to the unity of the teaching of the hierarchy throughout the world and to its concern for adaptation according to time and place.

"The labour problem in the light of the social doctrine of the Church" is a masterly work which, besides stimulating anew the apostles of social welfare, pushes forward considerably the progress of Christian social science. These are two reasons more than sufficient for rejoicing at the "Faculté des sciences sociales", the "Département des relations industrielles", and the Industrial Relations Bulletin.

The EdrToRs

\section{CARTELS AND PRICE ARBITRATION}

\section{Maunice Lamontagne}

\section{Monopoly, Trust and Cartel}

Recent events have brought forward the problem of cartels as more than ever the problem of the day. Before attempting to define what we mean by cartel, we must clearly specify the differences between a cartel, a trust and a monopoly, which are often neglected. Monopoly corresponds to the situation where there is only one seller of a given product in the market, who consequently finds himself in a position to control at will production and prices. The are two ways in which a monopoly may be operated. The first is that of the trust, where a single firm runs the monopoly. For example, Canadian Industries Limited is a trust, for it has a monopoly on the production of many chemical products. The second form of monopoly is the cartel. It consists of an association of several producers of the same product who have agreed to follow a single price and production policy. The pulp and paper industry, for instance, was, at least until recently, organized in the form of a cartel. Canadian Industries Limited, which possesses a monopoly on many products in Canada, is a member, along with Imperial Chemical of England and Dupont de Nemours of the United States, of the international cartel in the chemical industry.

\section{Ways of Forming Cartels}

The movement toward cartelization has been intensified, especially during the last twenty years, in Canada as elsewhere. Generally speaking, one can say that a cartel exists in every industry where the number of firms is restricted. It is possible, therefore, to gain an idea of the extent of the movement by ascertaining the importance of a restricted number of firms inside their respective industry.

As to the exact number of cartels in existence at the present moment it is absolutely impossible to determine. This impossibility is attributable to the varied methods of organizing cartels.

Actually the agreement between producers which is the basis of a cartel can be either formal or only implicit. In turn, a formal agreement can be either written or verbal. There is an implicit agreement when, for instance, without any previous meeting, the smallest producers in an industry follow the policy and imitate the actions of the largest firm or firms. In the still recent past there was no formal and precise agreement between the different steel producers in the United States. Yet for all that the steel cartel was not less effective, for all the firms followed the lead of the United States Steel Corporation and applied in their turn its decisions regarding prices and volume of production. Most in vogue today, certainly, are the methods of verbal agreement and implicit agreement, and it is precisely for this reason that it is not possible to estimate, even approximately, the number of cartels.

\section{Cartels and Legislation}

Governments cannot remain indifferent to the rapid multiplication of cartels, for their normal consequences, which consist principally in systematic restriction of production and abnormal in- 
crease in prices, are absolutely incompatible with the needs of the general welfare. Actually, cartels have baneful effects in all sections of the economy: they engender unemployment, they contribute to the undue rise of the cost of living, they bring with them an unjust distribution of the national revenue by assuring swollen profits; they are the very negation of an economy of free competiton and they are in flagrant contradiction to capitalist doctrine.

In Canada the Combines Act forbids agreements which are prejudicial to the public interest. Firms that set up such agreements are subject to prosecution and can be sentenced to pay fines. This law falls under the jurisdiction of the federal government and it pertains to the commisioner in charge of applying it to undertake the necessary investigations to find out the agreements. However, the prosecutions in court are under the jurisdiction of the provincial governments.

We must not forget that the law does not prohibit cartels in themselves. For it to apply it must be proved not only that there is a restrictive agreement but that this agreement is contrary to the public interest. The limitations of this law are numerous and merit special attention.

1. In the first place the law does not cover the case of trusts. It is certainly paradoxical to discover that it prevents a group of firms from agreeing to act contrary to the public interest, but it does not prohibit one company alone from buying up competing firms to set up a monoply and exploit the public. The «Famous Players» company is a case in point.

2. As for the cartels themselves, the law demands first of all that a direct proof of the existence of a restrictive agreement be established, for the accused are presumed innocent. It is practically impossible to establish such proof, if there is no written agreement between the firms. So all the cartels that have no written agreement, and by far the largest number of them do not, can elude the law quite easily.

3. Not only must the written agreement exist, but also the public officials must learn of its existence and be able to discover it. These two conditions are not easily fulfilled, for the members of a cartel rarely brag about having signed an illegal agreement.
4. Once the existence of the agreement has been directly proved, the law further requires that the public prosecutors be able to demonstrate to the satisfaction of the court that the said agreement is contrary to the general interest. This second requirement of the law is probably more rigorous than the first, for it gives free rein to subjective interpretations.

5. When, following the long and difficult procedures required, the court finds the proof sufficient, it imposes a fine on the members of the cartel and orders the agreement to be broken off. The fines imposed are ridiculously small since they cannot exceed $\$ 10,000$ for an individual and $\$ 25,000$ for companies. Thus the sums that have to be paid as a result of a conviction are far inferior to the advantage drawn from the agreement. As to the order to end the agreement, it is rarely carried out. Ordinarily the written documents are done away with, but the cartel itself remains just as effective as before thanks to a verbal or implicit agreement.

6. Besides the limitations of the law itself we must add that they have given the administrators neither encouragement nor the personnel necessary for effective action.

The present law, to which have been appended some amendments of secondary importance, has been in force since 1923. During that period 20 investigations were carried out and 9 cartels were discovered, of which probably 4 were dissolved following conviction. When we consider that during the same period the movement toward cartelization and trust forming gathered considerable momentum in Canada, we cannot fail to recognize that the present law is far indeed from offering a satisfactory solution to the problem of monopoly.

Paradoxically enough, it seems that the law is too exacting and wishes to accomplish too much. It is supposed to prevent the establishment of or to dissolve cartels contrary to the public interest. The naive belief in the possibility of a return to, and of the maintenance of a system of pure competition constitutes the fundamental defect of the conception on which the law rests.

Yet the only practical and effective way to do away with a cartel is to nationalize the firms which make it up. As long as they subsist, by what system of surveillance can we manage to 
prevent their directors from communicating with one another and agreeing in one way or another to safeguard their interests which rarely coincide with those of the public ?

This radical solution, however, is not compatible with the structure of capitalism, and its application would signify a change in the economic regime. We must not forget that the normal evolution of the capitalist system leads almost inevitably to the trust and the cartel. A law forbidding this evolution may satisfy the many who are content with a false security, but most often it becomes inoperative, because the juridical superstructure cannot effectively oppose a fundamental tendancy of the economic structure. Let's be realis. tic, then, and recognize that in accepting capitalism we are also, even in the juridical sphere, accepting the existence of trusts and cartels.

\section{Toward a Realist Solution:}

\section{Price Arbitration}

Well then, since it is impossible to extinguish these attempts to monopolize the market, does that mean that we must stop opposing them ? Far from it. But it does mean that we must find a solution with which we can hope to achieve definite results. Since it is very difficult to prevent the existence of trusts and cartels within a capitalist structure, let us at least search for a way to avoid their most harmful effects on prices and production.

The solution which is offered is not new, for it has already been applied to a very important sector of the economy : the labour market. The advent of labour unions posed new problems in a society where wages and prices were supposed to be determined by the mechanism of competition. Labour unions try to monopolize the labour supply in order to permit the workers to negotiate on an equal footing with their employer. Left to themselves, in certain circumstances, labour unions might be in a position to force up unduly the level of wages.

It is with a desire to protect the employer, who is the consumer in regard to labour, that the right to strike has been conditionned by sompulsory wage arbitration. The system of compulsory arbitration has not done away with any fundamental right of the workman, because the arbitration award is not enforceable. In this system workers always have the right to determine the price of their labour and to strike for what they want. However, the compulsory arbitration system helps to slow the upward march of wages. First of all it brings about a reduction in the number and size of demands for wage increases by compelling labour unions to justify their demands before a tribunal. Further, it has been proved that in normal conditions labour unions cannot gain much except by conforming to an arbitration award, especially when the award is considered just. The result is that it is accepted in most cases, even if it grants only a part of the workers' demands. Therefore we can conclude that compulsory arbitration has at least prevented unjust wage increases.

This technique can be applied equally well to the domain of prices. Compulsory price arbitration would contribute at least as much as compulsory wage arbitration to the avoidance of unjust increases. The fact alone of obliging producers to demonstrate before a tribunal the necessity of a price increase would have the immediate effect of eliminating the increases which industrial leaders considered incapable of public justification. And even if the arbitration award is not enforceable, business firms would have to conform to it more or less, because in the public eye they would scarcely be in a position to impose a price increase which had just been declared unjustified. Finally, in the cases where they might not conform, the labour unions could demand part of the unjustified increase, which would constitute a compensation for the majority of consumers.

Compulsory arbitration can be applied to the whole price structure. It directly attacks the baneful consequences of cartels and trusts without requiring a previously established proof of their existence. These attempts at monopoly have the purpose of restricting production in order to maintain prices at too high a level. Compulsory arbitration, by helping to lower prices, would indirectly bring about an increase in production, for industrial leaders would have to adapt their scale of operations to the new situation. In other words, compulsory arbitration, though true enough it does not attack the cartels and trusts directly, removes the objective for which they are organized, which is probably the best means to make them disappear.

Moreover, a firm doesn't have to be a trust or a member of a cartel to succeed in imposing exaggerated prices. In other words, it is not es- 
sential to possess a perfect monopoly to control the market and get away with unwarranted prices. No trust busting or cartel breaking legislation can remedy this situation; the only satisfactory solution is compulsory price arbitration.

Finally, the application of such a system would bring about greater returns from and a better utilization of the nation's productive ressources. First of all, by helping to lower prices it would stimulate production, which would mean a more effective scale of operations and a trimming of unused productive capacity. In the second place, we must note that in many cases the increase or the continued high level of prices is motivated solely by poor administration of the firm. There is not enough effort made to obtain the best possible returns from the productive plant. The present system by which managerial incompetence or carelessness keeps prices rising constitutes a bonus for inefficiency and leaves society to foot the bill. With price arbitration firms would sooner or later improve their administrative system or very well pay the cost of their own inefficiency.

To sum up, this reform is not inspired, like the present Combines Act, by the naive belief in the possibility of a return to a system of pure competition, which has never existed and never can exist. It takes the industrial organization as it is, with its monopolistic tendencies, and strives so to reorientate it as to produce those advantages which the competitive system claims to offer.

Compulsory price arbitration is not new. Up to now, however, it has been applied to only a limited sector of the economy, the public utilities. This group comprises the different forms of transportation, telephones and electricity. And in the present system the arbitration awards or, if you will, the decisions of the administrators charged with representing the public interest, are enforceable.

What is new in the present proposition is that it applies the arbitration principle to the prin- cipal sectors of the economy where it seems desireable, without making the arbitration award enforceable.

This reform seems amply justified by the happy consequences it gives hope of. And it presents no serious inconveniences. As far as administration is concerned, for instance, it involves much fewer complications than price controls, which nevertheless functioned effectively during the war.

On the other hand, it may be charged that compulsory price arbitration restricts the prerogatives of private enterprise. But if we look a little closer we see that it guarantees much more than it limits the liberty of enterprise. It simply requires that industrial entrepreneurs render an account of their actions to public autority. Without diminishing the liberty of enterprise it reminds it of its social responsibilities. From this point of view price arbitration can help protect private enterprise from itself, for if it does not become more social, it is running the risk of sooner or later being socialized. Price arbitration will certainly make it more difficult to increase prices unjustifiably, but no one can pretend that free enterprise implies the right to keep prices at an exaggerated lever and systematically to exploit the consumers.

Besides, even if, after such a measure is applied, producers have the impression they are less free, their situation would certainly not be worse than that of their employees. In a demcoracy that is really what it pretends to be, how can anyone be opposed to the arbitration of the prices of merchandise, when the price of labour, that is to say, the revenue of the great majority of consumers, is already subject to this system. Effective price arbitration constitutes one of the foundations of economic democracy and an effective method of combatting cartels, trusts and all the other pre sent tendencies toward monopoly.

\section{Do you need an industrial relations counsellor ?}

We can supply you with the names of specialists in this field who have both theoritical training and practical experience.

For further information, please communicate with Jean H. Gagné, secretary of the Département des relations industrielles, Faculté des sciences sociales, Université Laval, 2, rue de l'Université, Québec. 